\title{
Improving the practice of Competitive Strategies for the protection of Intellectual Property: the law and economics approach
}

\section{Vladlena LISENCO*}

\begin{abstract}
The article contains analyze of the legal regulation of the protection of intellectual property rights and practice of competitive strategies for the protection of intellectual property using best legal practices of EU countries and Eurasian Economic Union. Legal confirmation of intellectual property right, in fact, means that the state realizes the importance of culture and progress for the preservation and development of society. Protection of the results of creativity, intellectual activity is associated with the protection of individual freedom, human rights. The features of the competitive environment and competitive mechanism in the innovation economy has been analyzed as well as influence of competition on the behavior of economic agents in the innovative economic system. The paper includes analyzes the logic and economics of non-competitive behavior of companies and states in the EU single market and examines the functions of the Directorate of the European Commission for Competition. The EU competition policy tools are flexible and that they take into account the most diverse interests of the single market. The policy of the Eurasian Union as a whole is aimed at the implementation by the member states of measures in competitive policy and contributes to the launch of joint research and industrial projects, allows to increase the competitiveness of products, reduce production costs, ensure joint access to the external market.
\end{abstract}

Key words: intellectual property; competition: innovative development; technology rights; copyright; patent law; international agreements; foreign investment.

JEL Code: K 11, K 33

\footnotetext{
* Vladlena LISENCO is Doctor Habilitat in law and University professor at Transnistrian University named after T.G. Shevchenko, Tiraspol. ORCID ID: 0000-0002-9846-2750 Email: vlada.lisenco@gmail.com
} 


\section{Introduction}

One of the most characteristic phenomena of the XXI century is the intellectualization of world trade, i.e. an increase in the share of the «intellectual» component in goods and services. In developed countries, intellectual property rights (IPR) have long been an important element of economic development, it is this group of countries that is most actively involved for strengthening the protection of IP rights within the framework of both bilateral and regional and multilateral treaties.

It is impossible to pick out a single theory that would study intellectual property (IP). Within the economic theory, a large number of possible models have been proposed, which will not be unequivocal due to the complexity and heterogeneity of innovative activities and the obvious problems that arise when evaluating such items.

A multi-criteria approach to the classification of intellectual property can be presented as follows: a) by structure (institutions of intellectual property) b) by items of protection c) by the sign of the impact of intellectual property forms on the market system.

Purpose of this study is to explore to what extent, in what manner and with what objectives intellectual property has been considered in innovation policy making. Another area of research is competition policy, antimonopoly policy and policy in the field of intellectual property rights protection.

As concerns the importance of IP for innovation activity, the four major IPRs are patents, trademarks, design rights and copyrights. We define innovation policy as public intervention to support the generation and diffusion of new products, processes, services or business models (Mackaay, 2018). This is a very broad definition, that not only covers innovations that are exploited in the market place, but also those that are used in other domains (public sector innovation, social innovation). It also covers the support of innovation generation as well as the support for the exploitation, commercialization and adoption of innovation.

The most relevant aspects of the stated problematic area, in our opinion, are competition policy, antimonopoly policy and policy in the field of intellectual property rights protection. The study of the relationship between these aspects, requiring constructive analysis, is a topical issue. Competition is the basic mechanism of market relations. The paper tries to answer how competition should force entrepreneurs to compete with each other that results 
will be in cheaper and higher quality of produced products, meeting consumer needs and improving the economy. The subject of this study is the competition policy of the European Union and Eurasian Union. The paper analyzes the logic and economics of non-competitive behavior of companies and states in the EU single market and examines the functions of the Directorate of the European Commission for Competition. The article also formulates goals and assesses the four main directions of competition policy - the fight against cartels, control of mergers, control of state support, control of the activities of natural monopolies and public sector enterprises. The author comes to the conclusion about the flexibility of the EU competition policy instruments, taking into account in it the most diverse interests of the single market, the usefulness of certain distortions of the conditions of competition - mergers, acquisitions, certain types of state support - for increasing the competitiveness of the EU economy.

So, the paper research the basic economic principles of IP \& competition policy:

- IP: legal monopoly not per se a market monopoly

- IP: a "normal" good in competition policy?

- Where should competition policy come in

- Agreements (settlements, cross-licensing arrangements, pools)

- Monopolization, abuse of dominance

\section{Literature review}

IPR protection and competitiveness have been connected in the literature since the 1970s, although more prevalently during the late 1970s and 1980s, when IPR protection started to be framed as a competitiveness issue (Mokryshev, 2021).

Nowadays, IPR protection, is using by companies as a tool to attract investment (Torremans, 2004; Smarzynska, 2004), to create wealth (Schneider, 2005). It has been recognized as a source of competitive advantage (Singh, 2015). The use of patents by companies can provide a temporary technological lead and shape industry structure (Reitzig, 2004). IPR protection also allows these companies to develop innovative business models (Singh, 2015).

Competitiveness has been associated with the IPR protection and introduce technological breakthroughs and contribute to the vertical 
differentiation of the products and services (Reitzig, 2004). Prior studies have shown that startups play a key role in the generation of radical innovations (Colombo, Doganova, Piva, D'Adda, \& Mustar, 2015). Therefore, an appropriate IPR protection in this type of company can impact on their competitiveness.

At the moment, a certain theoretical and practical scientific base has been accumulated on the issues which are under scientific consideration. The role of innovation and intellectual capital in the economy at the macroeconomic level was studied by European, Russian, American and other scientists. The research review considers the legal articles in intellectual property rights, competitive strategies for the protection of intellectual property and its subtopics published during the 20th and 21 st centuries. The coverage is broad and comprehensive as possible, ranging from theoretical to practical and doctrinal. The authors who mentioned in the research paper are of the pieces under discussion and all stand as leading figures in their respective fields.

The problems of the impact of the intellectualization of the world economy and the need to regulate IP trade and competition policy on an international scale is the subject of activity within a number of international economic organizations, primarily the World Intellectual Property Organization (WIPO) and the World Trade Organization (WTO), under whose patronage numerous reports have been developed. Up-to-date statistical information is also provided by the World Bank (WB), The Organization for Economic Co-operation and Development (OECD), UNCTAD. We found in the literature as to the relationship of IPR and the various policy interventions selected by WIPO.

Despite the significant scientific apparatus, it should be noted that evolution of the provisions of numerous international documents, regulating the transfer of various IP objects and economic effects cooperation in this area, represents a wide field for research. The importance and need for in-depth analysis of the issues under consideration is strengthened by the constant expansion of the range of issues affecting IP rights (activities of intermediaries: exchanges, auctions, clearing companies in the field of IP, the rapid development of technology commercialization offices (Technology Transfer Offices), and increasing the scope of international IP trade regulations such as compulsory licensing 
pharmaceutical companies using patents on the human genome in the development of drugs against deadly diseases, the problem of trade in counterfeit products, etc.

\section{Data and Methodology}

Achievement of the goals determined the need to solve the tasks in the research: to analyze various theoretical and methodological approaches to the study of IP; to clarify the essence of the economic category of IP, to reveal the content of the process of development of intellectual property relations; to present systematically the contradictions of the IS relations as a driving force for the development of these relations; substantiate the need to protect IP from illegal distribution based on a comparison of world and other regional experience; study the impact of globalization on the formation and development of IP in new conditions; to identify the features of the IP model in EU and Eurasian Union.

To achieve the goals general scientific methods of cognition were used: system analysis and synthesis, and also methods of classification, comparison and typology for identifying and proving patterns and contradictions in the formation and development the international system of regulation of trade in objects of intellectual property; in addition, methods of systematization and generalization of statistical data were used. The research was also based on reports from WIPO, the WTO, the United Nations Conference on Trade and Development (UNCTAD), the World Bank, as well as the WIPO Statistics database and the UNCTAD / WTO International Trade Center (ITC).

The theoretical and methodological basis of the research is the scientific works of domestic and foreign specialists in the theory and statistics of intellectual property, on the development of the company and industry markets, strategic management, as well as the work of domestic and foreign authors on the problems of intellectual property management and the effectiveness of the development of the innovation sphere.

The information base was legislative acts on legal issues of economic development and intellectual property, materials and recommendations of scientific and practical forums, conferences and seminars on the problem under study; materials of periodicals; official statistical information and information on Internet sites. The methodological basis of this research is the methods and approaches that suggest that the study of all phenomena and processes is carried 
out in development, interconnection and interdependence, and the substantiation of the theoretical provisions of the work is based on the most important laws of economic development.

During the study and systematization of the data obtained, statistical methods for comparing generalized indicators, analysis of time series were used. The results of the analysis strongly suggest that there is a systematic, positive relationship between the ownership of IPRs and economic performance at individual company level. The present study provides an indication of this relationship, based on statistical analysis of a samples of individual firms. Finally, a cluster analysis was conducted on the data. We therefore collected information through a survey in line with some authors who have made efforts to discover which appropriation strategies small companies choose (Grešš, Martin \& Lipková, L’udmila, 2003; Thomä \& Bizer, 2013), and how these strategies have affected firm performance (Baculáková, Kristína 2015, Laursen \& Salter, 2005).

\section{IPR and antimonopoly policy}

The results of intellectual activity, knowledge, experience and especially the latest technologies represent the intellectual fund of any enterprise and are one of the main resources for its development. Creation of equal economic conditions for various types of commodity owners, the introduction of competitive principles into their activities and increased responsibility for its results, the need to saturate the market with goods and services causes an objective need for assessing and protecting intellectual property and means of individualization.

IP may make a positive contribution to society. Economic argument (Pretnar, 2003) and practical evidence (Fisher, 2007) suggest that patents encourage innovation and the dissemination of its proceeds, thus providing a base for further innovation; and they suggest that copyright may have a role in encouragement of creativity.

IPR is base of natural rights. Thus, the rights of the IP owner are not unlimited. There are restrictions on duration and territorial scope, requirements which must be met for the rights to exist and for the IPR owner to be able to exclude in a particular situation. Sharing may be required through compulsory licensing and some conduct is permitted in any event (for example fair dealing, use for noncommercial purposes and use of one's own name (Drahos, 1996). 
Patent law deals with industrial property, i.e. exclusive rights exercised in the sphere of production, trade circulation, provision of services, etc. But the legislation does not consider the means of individualization of entrepreneurs and their products as the results of creative activity and does not recognize any special rights for their specific creators. When it comes to the legal protection of intellectual property items, the main function is to ensure the individualization of producers and their goods, works and services (Suhanov, 2019).

Firms use IPR initially to secure exclusive rights over their inventions, but they also use them to signal technological and design capacity, to build up reputation and strength in the market place (Somaya, 2012), increasingly also as ammunition against competitors, e.g. in bidding wars (Anderman, 2000).

Brand names, which are the commercial name of an enterprise, are inseparably associated with its business reputation. Under this name, an entrepreneur makes transactions and other legal actions, bears legal responsibility and exercises his rights and obligations, advertises or sells his products. The brand name, which has become popular with consumers and has business partners' credit, brings the entrepreneur not only income, but also well-deserved respect in society and recognition of his merits. That is why the right to a brand name should be considered as an important personal nonproperty good. The use of the brand name also fulfils an essential information function, since it informs third parties of the ownership, type and organizational form of the enterprise.

The trademark and service mark, which are used to mark the produced products and provided services, are an active connecting link between the producer and the consumer, acting as a silent seller. Along with its distinctive function, a popular trademark evokes a certain perception of product quality among consumers. One of the important functions of a trademark is also the advertising of produced products, since a trademark that has gained the trust of consumers contributes to the promotion of any goods marked with this sign. It is also known that on the world market the price of products with a trademark is on average $15-25 \%$ higher than the price of anonymous products. Finally, a trademark serves to protect products on the market and is used for fighting unfair competition.

Such means of product designation as an appellation of origin fulfil similar functions. Along with them, the designation of a product by an appellation of its origin is a guarantee that the product has special unique 
properties due to the place of its production. By ensuring the legal protection of appellations of origin, the state protects and stimulates the development of traditional crafts and trades, whose products are always in great demand among consumers.

Thus, the legislation of different countries on the means of individualization is an important part of the legal protection of intellectual property items. In some countries, in addition to traditional items protected by copyright and patent law, as well as by legislation on means of individualization, protection is provided for selective breeding results, topologies of integrated circuits, official and commercial secrecy information, and some other results of intellectual activity.

Thus, intellectual property is a collective concept used to denote the rights to the following: the results of intellectual (creative) activities in the sphere of literature, art, science and technology, as well as in other spheres of creativity; means of individualization of participants in civil circulation, goods or services; protection against unfair competition.

It is extremely difficult, if not impossible, to give an accurate and universal definition of intellectual property, since the content of the concept of intellectual property changes with the development of technology, market relations and legislation, and the rights united by this concept are very heterogeneous (Friedman and Barak-Erez, 2001).

The rights of the IP owner are not unlimited. There are restrictions on duration and territorial scope, requirements which must be met for the rights to exist and for the IP owner to be able to exclude in a particular situation, sharing may be required through compulsory licensing and some conduct is permitted in any event - for example fair dealing, use for noncommercial purposes and use of one's own name.

Intellectual property refers to creations of the mind - everything from works of art to inventions, commercial signs, computer programs, trademarks and other commercial signs. More direct challenges to IP were seen at the World Intellectual Property Organization (WIPO), which is a global forum for intellectual property services, policy, information and cooperation and which has mission to lead the development of a balanced and effective international IP system that enables innovation and creativity for the benefit of all. WIPO is an intergovernmental organization which co-ordinates international applications for trademarks and patents, administers IP treaties, and also has an educational role as countries review, plus establish IP regimes. Concerns arose 
that WIPO was not evaluating and considering fully the possible risks for developing economies of IP and its expansion into new fields.

Intellectual property is a specific subject to management with a number of special features, the significance of which increases in terms of the transition to an innovative economy. Intellectual property is a set of legal relations regarding the ownership, disposal and use of products of intellectual activity, exclusive rights to the results of creative activity and means of individualization (Delmas-Marty, 1992).

Intellectual property items are items of industrial and literary (artistic) property, the mechanisms of creation and protection of which are the same, while the conditions of commercialization are different to some extent. According to the classification of the World Intellectual Property Organization (WIPO), intellectual property items are works of science, literature and art; performing activities of artists, sound recordings, radio and television programs; inventions in all branches of human activity; industrial designs, trademarks, service marks, brand names and trade names.

At the present stage of development of the world economy, the world's leading companies have chosen a fundamentally new approach to economic growth issues, based on the intensification of the acquisition, use and transfer of knowledge. The results of intellectual activity, knowledge, experience and especially the latest technologies represent the intellectual fund of any enterprise and are one of the main resources for its development. (Bartels, 2006)

It is no coincidence that the interests of the leading countries of the world lie in the sphere of accelerated growth of knowledge. As the economy moves towards a more knowledge-based development model, the results of intellectual labor become one of the main assets not only of individual enterprises, but also of the state as a whole, and the exchange of these results has now become an independent sphere of international economic relations (Baculáková, 2015).

Nowadays IP is no longer considered as a by-product and a result of the development of a new type of product, but as a serious weapon in the competitive struggle. Hewlett Packard beat off competition in the market of ink-jet printers by significantly investing in laboratory research and protecting the development results with a large number of patents.

Given that the income from the use of $R \& D$ results are significantly reduced in case of their illegal use by competitors, IP began to be used not only as a defense, but also as an offensive weapon in competition. An example of the successful use of IP in corporate strategy is Texas Instruments company 
(USA). In the 1960's, the company was making its «patent portfolio». By the mid-1980's, the company changed tactics to offensive and began pursuing companies that illegally used its intellectual property. The settlement of claims helped Texas Instruments earn significant income. In 1991, income was \$ 256 million. The total income earned by the company in 1986-1993 from the use of IP was $\$ 1.2$ billion. In the early 1990's, INTEL invested \$ 1 billion annually to control the production of microprocessors. Despite such huge expenses, the company's rate of return, according to the data that it submitted to the tax authorities, was $25 \%$.

In a tough competition, the winner will be the company that makes the most productive use of its resources. In this regard, the development of the corporate strategy of the company is very important.

The intellectual capital growth is due to the characteristic features of technological development, the mechanism for the expansion of new technologies in the economy, the transfer of new knowledge and intellectual property. This growth is primarily due to the use of information technologies. Researchers predict the emergence of other basic innovations in the near future. (Čech, 2011).

The processes of the intellectual capital growth are directly dependent on the institutions and rules formed by the state that regulate the possibilities of using this capital. The system of such institutions includes institutions of monitoring intellectual capital; institutions of investing in entities that provide capital accumulation; institutions of the transfer and replication of intellectual products, which play a decisive role in increasing the efficiency of the innovation process and ensuring the organization of the main flows of knowledge and information in the modern economy; institutions of the protection of intellectual property rights; institutions of access to valuable information and knowledge.

The most relevant aspects of the stated problematic area, in our opinion, are competition policy, antimonopoly policy and policy in the field of intellectual property rights protection. The study of the relationship between these aspects, requiring constructive analysis, is a topical issue.

Antimonopoly policy is a protective component of competition policy aimed at ensuring competition by using methods of controlling the level of market concentration, preventing (suppressing) abuse of a dominant market position, restraining competition of agreements and concerted actions. The 
specific properties of intellectual property items necessitate the development of special approaches to the application of antimonopoly policy tools.

\section{EU policy on competition}

In the European Union, where the barrier function of internal state borders has been eliminated, there are no national obstacles to market relations, discriminatory restrictions on the movement of goods, services, capital, labor, legal entities and individuals are prohibited. The single market was created and continues to develop for improving the economies of the EU member states and improving the living standards of its citizens. This development is based on the idea that international economic competition, developing in terms of market unity, creates an impetus for improving the quality and lowering the prices of goods and services, improving the division of labor, improving the organization of production, specialization and savings on increasing the scale of economic activity, the development of the latest achievements of science and technology (Grešš, Lipková, 2003)

Fair competition causes rapid economic change, the creation of high-tech start-up companies. All of this can be a more effective tool for economic development than protectionism or state support for dying companies. Back in 1957, the preamble to the Treaty of Rome of 1957, which laid the foundation for the European Economic Community, said that removing the barriers dividing Europe requires concerted actions to ensure fair competition.

The Treaty on European Union contains general provisions regarding competition policy in two subsections: one is about the behavior of companies in the market, the other is about the behavior of states. The Treaty of Lisbon barely addressed the basic provisions on competition. All of them, like before, are being implemented through the issuance of appropriate regulations, directives and decisions and subsequent control over their implementation. Most of the regulations in this area are issued by the European Commission (EC) and do not require approval by the Council of Ministers.

Finally, acquis communautaire in the sphere of competition is enriched on a regular basis by the practice cases of the EU Court of Justice (Ispolinov, 2010). To make it easier for enterprises and states to sort through the whole variety of institutional rules and judicial precedents, the Commission issues reports, guidebooks, main directions of regulation and other informational and advisory publications. 
Article 14 of the Treaty of Lisbon maintained the subsidiary basis for rulemaking. The competence of the EU includes the following: promoting the improvement of the quality and reliability of natural monopolies, the availability of services of general economic interest and ensuring conditions for a reasonable reduction of the cost of these services, freedom of movement across the internal borders of the EU and increasing the level of transparency of the work of the relevant enterprises; protection of the rights of consumers of such services.

The European Commission considers contacts between enterprises as widely as possible. The discovered verbal and written agreements, decisions, contracts, conventions, associations are taken into account. The main thing for it is not the form, but the content of the practice of interaction between enterprises. The prohibition under Article 101 can be imposed both on horizontal agreements (price cartels and collusion to divide the market into exclusive rights zones) and on vertical agreements (between suppliers and dealers on fixing prices or exclusive dealerships in a certain territory) and binding agreements (for example, on the purchase of a product only in case of a following purchase of another product).

The nature and time of the impact of non-competitive behavior on the market is just as broadly considered. On this point, there is a precedent decision of 1967 of the Brasserie de Haecht case (aff. 23/67, R.p.525). With regard to the impact of non-competitive behavior of enterprises, in this decision the Court used the following wording: "which may have an impact, directly or indirectly, in the present and in the future, on the trade exchange between Member States ...». The EC Communication of April 27, 2004 fully confirms such a broad approach.

As for the large horizontal agreements, licensing agreements for technology transfer, specialization agreements, franchising, insurance, R\&D transfer agreements have been approved, as they generally lead to improved production and distribution of products, as well as provide tangible benefits to consumers.

As it is known, the mutual opening of markets sometimes creates more problems for companies than opportunities. We are also talking about the possible dishonesty of the participants and the inefficiency of the cartel. Since the creation of the cartel, its members can not only deceive the market, but also deceive each other. For example, to release a little more goods than the cartel gives them. As a result, collusion keeps a large number of ineffective dishonest 
companies in the industry, which are still at risk of not finding demand for their goods. The consequences of collusion to divide a common market differ little from those caused by disunity of markets. In both cases, there is a large number of small companies, forcibly or intentionally maintaining high prices for products due to the small scale of their activities. In both situations, high prices lead to low demand and, subsequently, an lowered supply.

Non-competitive behavior, as a result of which the company receives inflated income by collusion with competitors, is interpreted by society as fraud, and therefore should be punished. We cannot but mention the collusion between eight well-known vitamin companies*'. These companies were caught out to be involved in ten years of cartel practice in the European internal market. They regularly exchanged data on sales volumes, coordinated prices, monitored annual profits, adjusted and quotaized output, for which they were punished. This example of collusion came down in history due to the very high fine of 1 billion euros imposed on the cartel in 2001. In particular, the fine imposed on the leader of the cartel, which is a Swiss company, was 462 million euros.

In 2016, the European Commission announced a fine for the largest European truck producers for a record amount in the European Union for violating antimonopoly laws. The decision marked the end of a five-year investigation of Scania, Iveco, DAF, Volvo, Daimler and MAN. The European Commission accused them of price collusion to slow the development of new technologies to reduce harmful emissions. Major truck producers drove up prices and hindered the struggle against polluting emissions since 1997.

Mergers and acquisitions are recognized as acceptable alternatives. It should be immediately noted that mergers and acquisitions are sometimes carried out painfully for states and society, since, as a rule, they are accompanied by job cuts and the liquidation of individual divisions. At the same time, a merger can result in dominance, which put fair competition at risk. Therefore, since the end of 1989, the European Commission has had full competence to control the sphere called the concentration of production in political economy.

There are vertical agreements between companies operating at different points in the production or distribution chain. An example of non-competitive behavior in this case would be an agreement between a company and

\footnotetext{
* Swiss Hoffman-La Roche, German BASF и Merck, French Aventis SA, Dutch Solvay Pharmaceuticals and Japanese Daiichi Pharmaceuticals, Esai andTakeda Chemical Industries.
} 
distributors of its products on fixed prices or about exclusive dealership in a certain territory. Nintendo and seven of its distributors were fined 168 million euros for «dividing» the EU single market in the 1990s and setting excessive prices in those parts of the market where consumers could pay more.

The participants of the collusion managed to maintain a noticeable difference in the prices for game consoles and games by manipulating natural language barriers. For example, the release of copies of this product in German was so limited that the offer prices in Germany were $65 \%$ higher than the prices in the UK. The price differences could be lowered by the efforts of independent dealers who could buy the product in the UK and sell it in Germany. The Nintendo cartel obstructed the emergence of such companies.

A few words about the essence of dominant position. A company that can offer an innovative product to a mass-market consumer, as a rule, has a strong position in the market. High demand drives the distribution of the product and the company achieves the desired dominance position. The more supporters, the more actively the consumption grows. As a result, the product either displaces existing analogues from the market, or objectively does not give them the opportunity to appear. A classic example is Windows system from Microsoft, which has standardized the work of personal computers around the world. Consumers were extremely interested in such a product. Thus, the highest demand caused a dominant position. The value of this standardization (as well as any standardization) was that the majority of consumers use the same product, which creates a number of the following advantages: the possibility to combine production activities, convenience of domestic use, etc. Many companies promoting their product (or standard) strive to achieve the same effect. In its turn, the market is also interested in the win of one standard over many incompatible/competing standards (an excellent example of this is the win of the GSM standard for mobile communications).

As for Microsoft, its largely innovative approaches to win consumers threatened to knock out other quite competitive systems from the EU market space. It was fined in 2004 and again in 2008 for abusing its dominant position in the European market of operating systems during the period from 1998, or more precisely for the threats associated with a lack of alternatives. In EU practice, this is the only case when a second fine was imposed on a company, calculated taking into account the non-payment of the first one. The total amount of sanctions against Microsoft have reached 899 million euros so far. 
European Commission managed to disclose collusion between four car glass producers*. The Japanese firm Asahi decided to work with the Commission and helped disclose the collusion. In return, when calculating the amounts of penalties, the company was given an incentive discount of $50 \%$. In 2008 , the cartel was fined an unprecedented amount of 1,383,896,000 euros. The French company was fined 896 million euros, while the fine imposed on Asahi was much smaller - 113 million euros.

The Treaty of the EU contains a prohibition (although not without clauses) on abuse of dominant position and intercompany collusion. The EU also controls other deformations of the competitive conditions, for example, caused by state subsidies. If enterprises manage to occupy $50 \%$ of the market or more, then this position is considered dominant (although there were cases when taking of $40 \%$ of the market was considered as dominance). The next thing is to find out whether dominance has a negative effect on trade, whether there are abuses in pricing (whether the high price is a consequence of high producer costs, or there is another reason) and sales policy, whether there are biased obstacles for competitors to enter the market, whether there are facts of discrimination against other market participants, and finally, whether there any additional obligations by partners that distort market conditions.

The company can be fined for non-competitive behavior. Since quite large companies come to the attention of the European Commission, then there are often sanctions in the amounts of hundreds of millions of euros (the figures of extremely high fines have already been cited above).

Regulation 1/2003 says that the fine must be quite high. Its purpose is to curb the attempts of EU market participants to engage in non-competitive behavior. Depending on the severity of the infringement, the fine is equivalent to $15-30 \%$ of the value of the company's sales related to the infringement. However, the maximum penalty may not exceed $10 \%$ of the company's annual turnover before the violation. Thus, the mission of the European Commission is not to bankrupt those who are guilty, but to deprive them of the profits obtained by dishonest means. When calculating the amount of the fine, the Commission takes into account both aggravating circumstances - leadership in the cartel, repeated violation ${ }^{\dagger}$ or evasion of company employees from testifying

\footnotetext{
* Asahi (Japan), Pil Kington (UK), Saint-Gobain (France) и Soliver (Belgium) companies.

† The cartel experience of Saint-Gobain is quite long. In the 1980's she was fined twice for noncompetitive behavior in the EU market. Then her participation in the cartel of car glass producers, mentioned above in connection with a unprecedented amount of sanctions of 1.383
} 
and withholding documents during the investigation - and mitigating ones* Enterprises have every right to apply for their own defense. They can avoid harsh sanctions if, in accordance with Art. 101 para 3 TFEU, they can prove that their activities contribute to technical or economic progress, provide a fair share of benefits to consumers, and improve production or distribution of goods. Dominance due to the possession of technology and know-how that competitors do not have, cannot be considered abuse; a well-known trademark and a developed distribution system also objectively help to maintain a dominant position. To defend their businesses, lawyers use consumer opinion surveys. Often this helps reveal a mistake in the conclusion of the Commission on the size of the market occupied by the enterprise. Art. 103 TFEU obliges the European Commission to formulate directives or decisions in order to comply with the above-mentioned provisions of the Treaty.

The single market is not without state support. The annual volume of financial assistance to the economy from the EU member states has reached about 65 billion euros (which is comparable to about $0.5 \%$ of the total EU GDP and general budget expenditures under the social and economic cohesion item). These are the data of the latest report of the European Commission on state support. On average, more than a quarter of state spending goes to environmental protection and energy saving projects; Sweden is the leader here. Up to $20 \%$ of state support is spent on helping lagging regions (Germany is the leader), on the development of $\mathrm{R} \& \mathrm{D}$, small and medium-sized businesses, employment - about $10 \%$ each, on vocational training - $2 \%$.

There are examples of state support in the EU: minor support, support to small and medium-sized enterprises, subsidies for creating new jobs, assistance to improve professional skills, state support for environmental protection, state support in saving and restructuring companies, state support to lagging EU regions, state support of services of general economic interest, state support to agriculture and forestry, state support to sea transport enterprises, etc. The basic provisions of the EU about the control of state support systems are set out in Articles 87 to 89 of the Treaty of the EU. Article 87.1 prohibits the payment of any type of support that threatens to distort the conditions of competition in the

billion euros, was proved. When calculating the fine for the last violation, the company was considered as a dangerous repeat offender

* Fine imposed on Sony for evading testimony and withholding information was increased by $30 \%$ in a price collusion case of three Japanese video cassette producers (Sony, Maxell and Fuji) disclosed by the EC in 2007. 
single market. The limits and types of allowable assistance are announced either in the form of Commission regulations or in the form of recommendatory documents (for example, «Guidelines» in a specific area of regulation), and, accordingly, can be mandatory or recommendatory. There is a special section on the Commission's website, where information about the prepared and adopted rules in the sphere of state support regulation, recent reports and other documents can be found.

Competition policy of the EU fulfills a number of socially and economically significant functions. Thanks to its mechanisms, firstly, access to goods and services is provided on more favorable terms for EU citizens, secondly, fair assistance to the development of companies in member states is provided, and thirdly, the competitiveness of the European Union in the world increases. Competition policy is carried out using a well-developed toolkit. All other areas of EU internal policy are subordinated to its goals.

Within the framework of competition policy, some legal mechanisms are allowed and recognized as useful - mergers, acquisitions, certain types of state support, since they serve to increase the competitiveness of the Union in the world. 350-400 mergers are carried out annually in the EU single market.

The EU competition policy, which is quite flexible in relation to companies of the member states, remains rather tough to external actors. Therefore, the world is closely watching the processes taking place in the economic policy of the European Union.

Companies located outside the EU are adapting to its legal regulations, including competition law. They are encouraged to do so because of the fear of not being admitted to the space of the single market. The same companies that have already entered this market are forced to unconditionally follow these rules.

The competition policy rules cover the 27 member states, as well as Norway, Iceland and Liechtenstein, connected with the EU by the European Economic Area. Turkey as a member of EU Customs Union have committed themselves to adapting their national competition policy to EU rules. In terms of control of non-competitive behavior of enterprises, Turkey has reached a high degree of consistency of its rules and actions with the EU competition law, however, in terms of state aid, as noted by the EU, there is practically no progress.

The EU actively shares with other regions and countries its achievements in the management of competition. Agreements on cooperation in the sphere of 
competition were signed with the USA, Japan, Canada. A special format of «Dialogues» is also used. In particular, within the framework of the concept of building a common economic space, a dozen sectoral dialogues are underway with Russia, including the task of approximation of competition laws and procedures for its application, as well as cooperation of antimonopoly authorities. The EU-China and EU-South Korea dialogue has begun. Thus, the European Union achieves the goal of communicating its experience to the outside world and discussing emerging problems.

\section{EAEU and IPR}

There is a direct interdependence between the growth of unfair competition and the lack of an intellectual property market in the countries of the Eurasian Economic Union (EAEU), including the Russian Federation. In general, the share of the intellectual property market in world trade in the XXI century has quadrupled (exceeds $15 \%$ of GDP) and continues to grow. On the other hand, the national intellectual property markets in the EAEU countries remained at the same level (less than $1-2 \%$ of patent sales of the total number of patents in force). Modern analyzes show that during the transition to the digital economy, the share of value added from the turnover of intellectual property in the pricing of produced goods, works/services and finances in general will only increase, which, in turn, will intensify competition, including unfair competition in this sphere (Leontiev, 2020).

According to the Development Strategy of the Information Society in the Russian Federation for 2017-2030, the formation of the digital economy is considered one of the national interests of Russia, including the following: the creation of new markets based on the use of information and communication technologies and ensuring leadership in these markets through the effective development of the Russian ecosystem of the digital economy (large Russian organizations in the sphere of information and communication technologies); increasing the competitiveness of Russian high-tech organizations in the international market; ensuring technological independence and security of the infrastructure used to sell goods and provide services to Russian citizens and organizations; protection of citizens against counterfeit and low-quality products; improvement of antimonopoly legislation, including while providing software, goods and services using the Internet to persons located on the territory of the Russian Federation; development of trade and economic 
relations with strategic partners of the Russian Federation, including within the EAEU.

By decisions of the EAEU supreme bodies, all EAEU member states are required to expand the range of tools that are used, intensify efforts to achieve and maintain macroeconomic stability, implement joint measures within the EAEU and national measures in key areas. The implementation of these measures implies the active involvement of the economic potential from the use of intellectual property in these processes: from pricing while collecting customs payments to the formation of intangible assets and the use of intellectual property as an investment resource in diversifying economies at all levels (Eremenko, 2020).

Based on the results of the analysis of legislation and law enforcement practice in the sphere of production, circulation and protection of intellectual property in Russia and other EAEU countries during the transition to the digital economy, stable contradictions (collisions), new challenges and patterns that require the adoption of priority measures in the sphere of antimonopoly regulation and protection against unfair competition both by changing the rules and the procedures for their application, were identified.

According to Article 7(3) of the Civil Code of the Russian Federation (CC of the Russian Federation), in cases where a violation of the exclusive right to a result of intellectual activity or to a means of individualization is recognized in accordance with the established procedure as unfair competition, the protection of the violated exclusive right can be carried out both by the methods provided by the Civil Code of the Russian Federation, and in accordance with antimonopoly laws. In accordance with the Federal Law of July 26, 2006 No. 135-FL On Protection of Competition, the possibilities of applying antimonopoly measures in the sphere of intellectual property are limited.

Thus, in the last decade, a stable contradiction has developed between the patent monopoly on the results of intellectual activity and the possibilities of developing competition in the markets of goods, works and services using such objects of patent law. The results of intellectual activity, often obtained with budgetary funding $(85 \%$ of all expenditures on research and development in the Russian Federation in 2019-2020 - federal budget funds), with a possible term of legal patent protection of 20 years, go into free use in two-three years from the date of issue of the patent. This is often used by foreign companies, including transnational companies (TNCs), which, with minor modifications, 
patent these technical solutions for themselves again. Over the past 10 years, the entire increase in the issuance of patents in Russia (5\%) was provided only by foreigners. At the same time, joint ventures are not created, licensing agreements with domestic producers are not concluded, thereby forcing out domestic companies from national markets in order to please the interests of international and foreign TNCs.

The globalization of world trade, the introduction of economic sanctions have actualized the legal problem of the exhaustion of the rights of a rightholder in relation to a trademark, which is a legal limitation of the legal monopoly on the use of the exclusive right to a trademark. Parallel imports, which is understood as the imports from abroad to the EAEU countries by importers of original goods that have the trademark of the rightholder, but without the permission of the rightholder, generates a conflict of interests of importers and rightholders claiming absolute powers to control parallel imports. In accordance with the Treaty on the EAEU and with the adoption and entry into force of the new Customs Code on January 1, 2018, the EAEU has a regional principle of exhaustion of law, while in the Russian Federation there is a national principle of exhaustion of law (Article 1487 of the Civil Code of the Russian Federation), which prohibits the imports of goods into Russia with trademarks placed on them without the permission of the rightholders. Under these conditions, a foreign rightholder may use the exclusive right to a trademark in bad faith and restrict the imports of specific goods into the domestic Eurasian market or implement a pricing policy that increases prices in this market. In order to ensure uniformity of approaches for resolving conflicts of private and public interests in antimonopoly regulation and protection against unfair competition, taking into account the clarifications of the Constitutional Court of the Russian Federation (Resolution of February 13, 2018 No. 8-P) in cases of bad faith behavior of foreign rightholders of trademarks, including the creation of the threat of a monopoly on their part on the trademarks of the EAEU countries, it is necessary to use the mechanisms of antimonopoly regulation and civil-law institutions to counteract the abuse of rights in the interests of realizing public interests for protecting competition, including state support of national goods producers.

At the same time, based on judicial practice, there is still a high legal uncertainty in the separation of unfair competition associated with the turnover of goods using the results of intellectual activity (RIA), and unfair competition associated with the circulation of exclusive rights to RIA data. At the same 
time, the provisions of the current Federal Law No. 135-FL of July 26, 2006 cannot be applied within the research, development and technological work (R\&D). That is why there are numerous abuses of the state customers of the use of previous intellectual property, where the rightholders are responsible parties or third parties (Mokryshev, 2021).

Despite the stated goals of harmonizing national legislation to build common markets in the EAEU in the sphere of intellectual property, protection against unfair competition and fighting counterfeiting, there are still fundamental differences among EAEU countries:

- system of protected items of intellectual property;

- determination of the rightholders of the RIA created with the use of budgetary funds;

- scope of rights to RIA;

- restrictions on exclusive rights to RIA;

- mechanisms of civil-law and customs protection of intellectual property;

- understanding of the institution of counterfeit and ways of protection against it;

- determination of the list of entities of unfair competition in the sphere of intellectual property and the specifics of their legal status;

- methods of unfair competition in the sphere of intellectual property and their identification;

- ways to protect against unfair competition in the sphere of intellectual property, including within the EAEU.

According to the Advisory Opinion of the Court of the Eurasian Economic Union of April 4, 2017 No. EC-2-1/1-17-GJ On clarification of the provisions of Articles 74, 75, 76 of the Treaty on the Eurasian Economic Union of May 29, 2014, competition law of the Union includes all three types of policies:

- unified competition (antimonopoly) policy of the Union (supranational regulation) to protect competition in cross-border markets;

- coordinated competition (antimonopoly) policy to protect competition in the national markets of the EAEU member states, including coordinated measures aimed at preventing and suppressing the circulation of counterfeit products;

- concerted competition (antimonopoly) policy in regard to the actions of economic entities (market entities) of third countries, if such actions 
may have a negative impact on the state of competition in the markets of the goods of the EAEU member states.

The application of policies depends on the following criteria: 1) the nature of the market (national or cross-border); 2) the nationality of the economic entity (market entity of a member state or market entity of third countries).

Successful law enforcement practice of antimonopoly regulation and protection against unfair competition in the sphere of intellectual property is an interdisciplinary topic, which involves the determination of the boundaries and rules of interdepartmental interaction at all levels (regional, national and interstate) while carrying out the functions of protection against unfair competition and fighting counterfeit, as well as a certain adjustment of the system of decisions preparation and decision-making in the EEC of the EAEU due to the persisting fundamental contradictions in the national laws of the EAEU countries and the existing autonomy of the ministers (board members) of the EEC and their subordinate departments.

If the goal of innovative development is competitiveness and the intellectual property market is a required condition for its success, then antimonopoly regulation and protection against unfair competition in the sphere of intellectual property can become a sufficient tool of ensuring such competitiveness.

\section{Conclusions}

1. When referring to the intellectual property concept and its content, it should be noted that this category has a rather long history of its development, just like any other civil-law institution, owing its appearance to the general patterns of the development of society, which has a dominant evolutionary path. The stages of development of the institution of intellectual property are determined, first of all, by the economic conditions and legal traditions of a particular country. As one of the main institutions of the information economy, IP creates the basis for the exchange of intellectual goods between economic entities, taking into account the interests of the owners of the transferred goods and consumers of intellectual products. A multi-criteria approach to the classification of intellectual property can be presented as follows: a) by structure (institutions of intellectual property) b) by items of protection c) by the sign of the impact of intellectual property forms on the market system. 
2. Legal confirmation of intellectual property right, in fact, means that the state realizes the importance of culture and progress for the preservation and development of society. Protection of the results of creativity, intellectual activity is associated with the protection of individual freedom, human rights. However, the dual nature of intellectual property law should be taken into account - its «spiritual» and economic components. Modern times are characterized by both the strengthening of the protection of personal nonproperty («moral») rights of the creators of intellectual values, and the further commercialization of property (economic) rights. The essence of intellectual property in terms of classical economic theory lies in the fact that intellectual property privatizes public knowledge, creates deficit and restricts access to certain information products. This enables the creator of an invention or work to control the consumption of this product and receive a reward for investment in human capital, which, accordingly, encourages further inventions. In terms of institutional economics, the essence of IP lies in the exchange of «bundles of rights» for intellectual goods, which is carried out in accordance with the system of rules regulating the ownership of intellectual products by certain entities.

3. It is impossible to pick out a single theory that would study intellectual property. Within the economic theory, a large number of possible models have been proposed, which will not be unequivocal due to the complexity and heterogeneity of innovative activities and the obvious problems that arise when evaluating such items. It is very difficult to objectively assess various combinations of various intellectual property items (innovation portfolio), state subsidies for innovative activities and other factors that affect the value of intellectual property items. The behavior of the company in a particular situation depends on all of the above-mentioned factors, for example, whether investments in development are made under the pressure of competition in the market. However, previous studies provided an interesting basis for analysis and also showed that there is no ideal model for promoting intellectual property. There are particular difficulties when the provisions of public law theory are applied. Problems arise when correlating public rights to created inventions and private rights of their owners. All that should lead to the development of new socially oriented institutions and to the development of an effective state strategy in the sphere of intellectual property.

4. One should remember that the economic environment is created over a long time and is not able to change quickly. The tool of this change is IP and 
it is advisable to interpret it in four aspects: as a value, a system, a process and a result. Intellectual property as a value should be considered as an integral part of intellectual capital, that is, as an asset that has the ability to generate income. As a system, intellectual property is an institution that includes a set of interacting elements. The possibility of involving intellectual property in the economic cycle, in which its productive consumption and growth is carried out, is expressed by the essence of IP as a process. Growth, in its turn, characterizes ownership as a result. The multifaceted aspects of the IP taken together makes it possible to increase the competitiveness of an economic entity.

5. In the innovative economy, the IP institution is developing dynamically and requires constant monitoring and changes in the rules and regulations according to which economic entities operate. There are new ways, technologies and mechanisms of interaction of economic entities regarding intellectual products; there are new institutions that regulate economic behavior in the conditions of the creation of a new type of economic system.

6. Intellectual property is closely related to such categories as property (since it is its type), innovation (intellectual property items are created in the process of innovation), illegal copying (piracy). The connection with the latter category is ambiguous, piracy can be considered both a negative factor in the market of intellectual services, and as an objectively existing phenomenon that opens an access to limited information at zero costs to a wide range of people.

7. Informatization of the economy implies a reconsideration of the role of the human factor as a source of scientific information. The specific feature of the intellectual product is in the specific nature of the process of connecting the worker with the means of production, where the subject and product of intellectual labor is information, and the labor itself belongs to the category of intellectual labor. Intellectualization of production is achieved through the use of qualitatively new information technologies, which contributes to the transformation of production into a system of network services.

8. Measures for the dissemination of new knowledge and the effectiveness of the mechanism for its practical implementation largely depend on the goals of state policy, and the quality of perception of the new attitude to state policy and entrepreneurial activity depend on each individual. The potential of intellectual resources and their transformation into human capital have a direct (and not mediated through the market) impact on the rate of economic growth, the level of national wealth and the well-being of the 
individual who is the monopoly owner of these qualities. Thus, in the new economy, the concept of national wealth includes intellectual resources along with property elements.

9. Antimonopoly policy is a protective component of competition policy aimed at ensuring competition by using methods of controlling the level of market concentration, preventing (suppressing) abuse of a dominant market position, restraining competition of agreements and concerted actions. The specific properties of intellectual property items necessitate the development of special approaches to the application of antimonopoly policy tools.

Acknowledgement: This paper is elaborated in the framework of the Jean Monnet Support to Associations in European Integration and Intellectual Property Protection Studies / EUPROIN, nr. ref. 611344-EPP-1-2019-1-MD-EPPJMO-SUPPA, implemented with financial support of the Erasmus+ programme of the European Union. "The European Commission's support for the production of this publication does not constitute an endorsement of the contents, which reflect the views only of the authors, and the Commission cannot be held responsible for any use which may be made of the information contained therein"

\section{References}

Anderman, S. D. (2000). EC Competition Law and Intellectual Property Rights. The Regulation of Innovation. Oxford University Press, Oxford, UK. pp.23-28.

Baculáková, K., Grešš, M. (2015). Cluster analysis of creative industries in the EU. - Registrovaný: Scopus. In Economic annals-XXI. Kiev: Institute of Society Transformation, no. 9-10, pp. 15-18.

Bartels, L., Ortino, F. (eds) (2006). Regional Trade Agreements and the WTO Legal System Oxford University Press, Oxford, UK. pp. 25-30.

Čech, L. (2011). Globalization and its influence on international political relations basic features of international political relations in the environment of a postmodern society of the globalizing world. In Globalisation dimensions \& impacts: global studies series Vol. 1. London: IJOPEC publication. pp. 75- 83.

Chen, Y., Thitima P. (2005). Intellectual Property Rights and Innovation in Developing Countries, Journal of Development Economics, 78(2), pp.474-493. 
Deepak, S. (2012). Patent Strategy and Management: An Integrative Review and Research Agenda, Journal of Management 38(4), pp.1084-1114.

Delmas-Marty, M. (ed) (1992). The European Convention for the Protection of Human Rights. International Protection versus National Restrictions International Studies in Human Rights Martinus Nijhoff Publishers Kluwer Academic Publishers Dordrecht, The Netherlands, Boston, USA, London, UK. pp. 115-118.

Grossman, G., Edwin, L. (2004). International Protection of Intellectual Property, American Economic Review 94(5), pp.1635-1653.

Grešš, Martin - Lipková, L’udmila (2003). Organizácia krajín vyvážajúcich ropu - 40 rokov existencie. In Ekonomický časopis = Journal of economics: časopis pre ekonomickú teóriu, hospodársku politiku, spoločensko-ekonomické prognózovanie. Bratislava: Slovak Academic Press, 51(2), pp. 203-216.

OECD (2020). Science, Technology and Industry. Economic Value. Working Papers, OECD Publishing.

Eremenko, V. (2020). Patent integration, Inventor and rationalizer, 5, pp. 1617.

Ispolinov, A.S. (2010). Acquis communautaire concept in the EU law. // Newsletter of the Moscow University, 11(5). pp.89-94.

Friedman, D., Barak-Erez, D. (2001) .Human Rights in Private Law Hart, Publishing Oxford, UK and Portland, Oregon, USA. pp.278-293.

Fisher, M. (2007). Fundamentals of Patent Law. Interpretation and Scope of Protection Hart Publishing, Oxford, UK. pp.305-310.

Kim,Y., Lee, K, Park, W., Choo, K. (2012). Appropriate intellectual property protection and economic growth in countries at different levels of development", Research Policy, pp.358-375.

Leontiev, B. (2020). Intellectual assets of the enterprise, Economy and life. No. 32. S. 15 (VIII). pp.54-59.

Machlup, F., Penrose, E. (1950). The Patent Controversy in the Nineteenth Century, Journal of Economic History, X(1) 1-29, pp.129-134.

Merges, R., Menell P., \& Lemley, M. (2003). Intellectual Property in the New Technological Age, Third Edition. New York: Aspen Publishers. pp. 7798.

Mackaay, E. (2018). Economic Incentives in Markets for Information and Innovation, Harvard Journal of Law and Public Policy, 13(3), pp. 79-81. 
Mokryshev, V. (2021). Investitsii i patentnaya politika, Delovoy mir, 9, pp. 1012.

Lerner, J., Zhu, F. (2007). What is the impact of software patent shifts? Evidence from Lotus v. Borland, International Journal of Industrial Organization, pp.511-529.

Torremans, P.L-C. (ed) (2004). Copyright and Human Rights Kluwer Law International, The Hague, The Netherlands. pp.90-99.

Suhanov, E.A. (2019). Ownership in the Civil Code and IPR. Law Journal, 11, pp. 23-35.

Scotchmer, S. (1996). The Economics of Intellectual Property: vol II Patents The International Library of Critical Writing in Economics 145, Edward Elgar Publishing Ltd, Cheltenham, UK. pp.89-121.

Sherwood, R. M. (1990). Intellectual Property and Economic Development Westview Special Studies in Science, Technology, and Public Policy Westview Press Inc, Colorado, USA and Oxford, UK, Sherwood. pp.367342.

Wooldridge, J. (2013). Introductory Econometrics. A modern approach", 5th edition, South-Western CENGAGE Learning. pp. 245-248.

Eurasian Economic Commission Report on the implementation of the main directions of integration within the Eurasian Economic Union (2019). Retrieved from http://www.eurasiancommission.org/ 